\title{
Logging decreases the pollen dispersal distance in a low-density population of the tree Bagassa guianensis in the Brazilian Amazon
}

\author{
By C. C. B. Arruda ${ }^{1)}$, M. B. Silva ${ }^{2)}$, R. Gribel ${ }^{3,4)}$, \\ M. R. Lemes ${ }^{3,4)}$, M. KANASHIRO ${ }^{5)}$ and A. M. SebBenN ${ }^{6), *)}$
}

(Received $8^{\text {th }}$ December 2015)

\begin{abstract}
This study investigates the distance and patterns of pollen dispersal before and after logging in a low-density population of the dioecious, insect pollinated tree species, Bagassa guianensis, in the Brazilian Amazon. All adult trees found before and after logging in a 500 ha plot were mapped and genotyped for six microsatellite loci. Seeds collected before and after logging were also sampled and genotyped. We used a categorical paternity analysis to determine seed paternity. Our results showed similar levels of pollen flow before $(23 \%)$ and after logging $(26 \%)$, but an increase in the mean effective pollination neighbourhood area, and a decrease in the rate of mating among relatives after logging, resulting in open pollinated seeds with lower levels of inbreeding (0.126) than before logging (0.222). We also detected changes in the mating pattern between before and after logging, a decrease in the median pollen dispersal distance and effective number of pollen donors after logging. Our results sup-
\end{abstract}

1) Federal University of Pará, Marajó-Soure Campus. $13^{\text {a }}$ rua Tv.19a Bairro: Umirizal, CEP 68870-000, Soure, PA, Brazil.

2) Federal University of Pará , Bragança Campus. Rua Leandro Ribeiro s/n, Bairro Aldeia, CEP 68600-000 Braganca, PA, Brazil.

3) Plant Genetics and Reproductive Biology Laboratory, National Institute for Amazonian Research (INPA), Av. André Araújo 2936, CEP 69083-000, Manaus, AM, Brazil.

4) Present Address: Scientific Research Group, Rio de Janeiro Botanic Garden Research Institute. Rua Pacheco Leão 915, CEP 22460-030, Rio de Janeiro, RJ, Brazil.

5) Embrapa Western Amazon, C.P. 48, CEP 66095-100, Belém, PA, Brazil.

$\left.{ }^{6}\right)$ Forest Institute of São Paulo, C.P. 1322, CEP 01059970, São Paulo, SP, Brazil

*) Corresponding author: A. M. SEBbenn. Forest Institute of São Paulo, Forest Genetics, Improvement and Conservation Group, C.P. 1322, São Paulo, CEP 01059970, Brazil. Phone: +0055 1934351681.

E-mail: alexandresebbenn@yahoo.com.br port the idea that reproductive trees should be maintained in the plot and around logged areas, using lowest levels of logging intensity to maintain pollen flow and decrease the relatedness of subsequent generations.

Key words: Dioecious species; paternity analysis; pollen dispersal; tatajuba; tropical tree species.

\section{Introduction}

Reduced impact logging (RIL) aims to minimize disturbances to the forest structure but inevitably decreases the effective reproductive density of trees in a logged population. Consequently, logged populations experience a genetic bottleneck immediately after logging (HAWLEY et al., 2005; LOURMAS et al., 2007; SEBBENN et al., 2012; LACERDA et al., 2013; ARRUDA et al., 2015). Genetic bottlenecks change the gene frequencies, causing a loss of alleles, particularly low frequencies alleles, and may reduce the heterozygosity of logged populations (RAJORA et al., 2000; LOURMAS et al., 2007; LACERDA et al., 2008; Silva et al., 2008). Logging usually increases the distance among reproductive individuals which affects pollinator behaviour (LOURMAS et al., 2007; LACERDA et al., 2008; SEBBENN et al., 2012). Consequently, the rate of selfing and correlated mating may increase, since the number of pollen donors participating in mating events may be reduced, resulting in a low variance effective size in open-pollinated progeny (LowE et al., 2005; AZEvEDO et al., 2007; LOURMAS et al., 2007; CARNEIRO et al., 2011; Degen and SebBenn, 2014). However, tropical tree species with low-density may be resilient to reductions in the reproductive population and maintain similar levels of outcrossing and pollen dispersal after logging when harvested at a moderate intensity (LACERDA et al., 2008; ARRUDA et al., 2015). The main limiting factor for regeneration after logging may be a reduction in the number of trees capable of 
producing seeds, rather than genetic effects due to limited pollen dispersal (LouRMAS et al., 2007).

In conservation biology, estimates of the patterns of gene flow through both pollen and seeds, mating patterns, variation in individual fertility, and effective reproductive population size are important factors in understanding the effects of anthropogenic processes, such as forest fragmentation and selective logging, on the genetic diversity of populations. These estimates are also necessary to establish strategies for conservation, logging, breeding, and forest restoration. The genetic structure of tree populations is determined largely by the movement of genes via pollen and seed dispersal (Dow and Ashley, 1996; BuRCZYK et al., 2004; Ashley, 2010; Ellstrand, 2014). Trees are stationary and, therefore, the location of an individual tree relative to conspecifics may influence the number of mates a tree has, the relatedness of the mates, and the relative fitness through male and female functions (Dow and Ashley, 1996). Studies of pollen and seed dispersal are particularly important for the world's remaining tropical rain forests, considering the very high species diversity, the fact that many of these species occur in a very low-density populations $(<1$ tree/ha), and the significant anthropogenic pressures affecting these biomes (DEGEN and SebBenn, 2014). Parentage analysis based on microsatellite markers is the most suitable method to assess the effects that logging and other anthropogenic interventions can have on population genetics of tree species (Dow and Ashley, 1996; BurCZYK et al., 2004; Ashley, 2010; ELLSTRAND, 2014).

Timber companies have intensely exploited the low-density, dioecious, insect pollinated, tropical tree species Bagassa guianensis Aubl. (Moraceae) in the Brazilian Amazon, due to the high quality of itse wood (SILVA et al., 2008). In dioecious species as $B$. guianensis, mating occurs among male and female reproductive individuals. The distance between reproductive individuals is very important because the pollination is insect mediate. Logging may change the distance among reproductive trees, decrease the population density, and affect the behaviour of pollinators, resulting in increased correlated mating. Thus, new generations would become more closely genetic related, consequently lowering the effective population size. Furthermore, increases in relatedness may increase the probability of mating among relatives, resulting in inbreeding. Assessing pollen migration, dispersion distance and patterns within open-pollinated progeny before and after logging is important to understand the possible impacts of selective logging on the mating system of this valuable timber species. In a previous paper, ARRUDA et al. (2015), using the same data set of the open-pollinated progenies of the present paper investigated the genetic diversity and mating system before and after logging based on the mixed mating model and correlated mating model, implemented in MLTR program (RITLAND, 2002). In contrast, in the present paper we used the adult trees and the open-pollinated progenies to investigate only the pollen dispersal distance and mating pattern before and after logging with base in paternity analysis. Although, we estimated one similar index, the mating among relative rate, our estimate is not based in models, but based only in the assigned seeds for a putative pollen donor within plots. Thus, the results presented here are novel and complement the ARRUDA et al. (2015) previous paper, showing the pollen flow and dispersal patterns before and after logging.

The study was carried out in an experimental plot established in a continuous natural forest in Brazil. Data was collected during one reproductive event before logging and three events after logging. Logging decreased the density of the reproductive population from 0.142 to 0.060 trees/ha. The surrounding areas of the plot were also logged, probably decreasing also the reproductive population density. Our hypothesis is that the decrease in the population density in the plot and surrounding areas and decrease in spatial genetic structure of reproductive individuals (Silva et al., 2008) due logging may affects pollinator behaviour, resulting in decrease in pollen flow and in the rate of mating among related individual after than before logging. Thus, our main question was: how did the decrease in population density resulting from logging influence pollen immigration and dispersal patterns and the rate of mating among relatives within the logged forest plot?

\section{Material and methods}

The study species

Bagassa guianensis occurs throughout the Brazilian Amazon as well as in Guyana and 

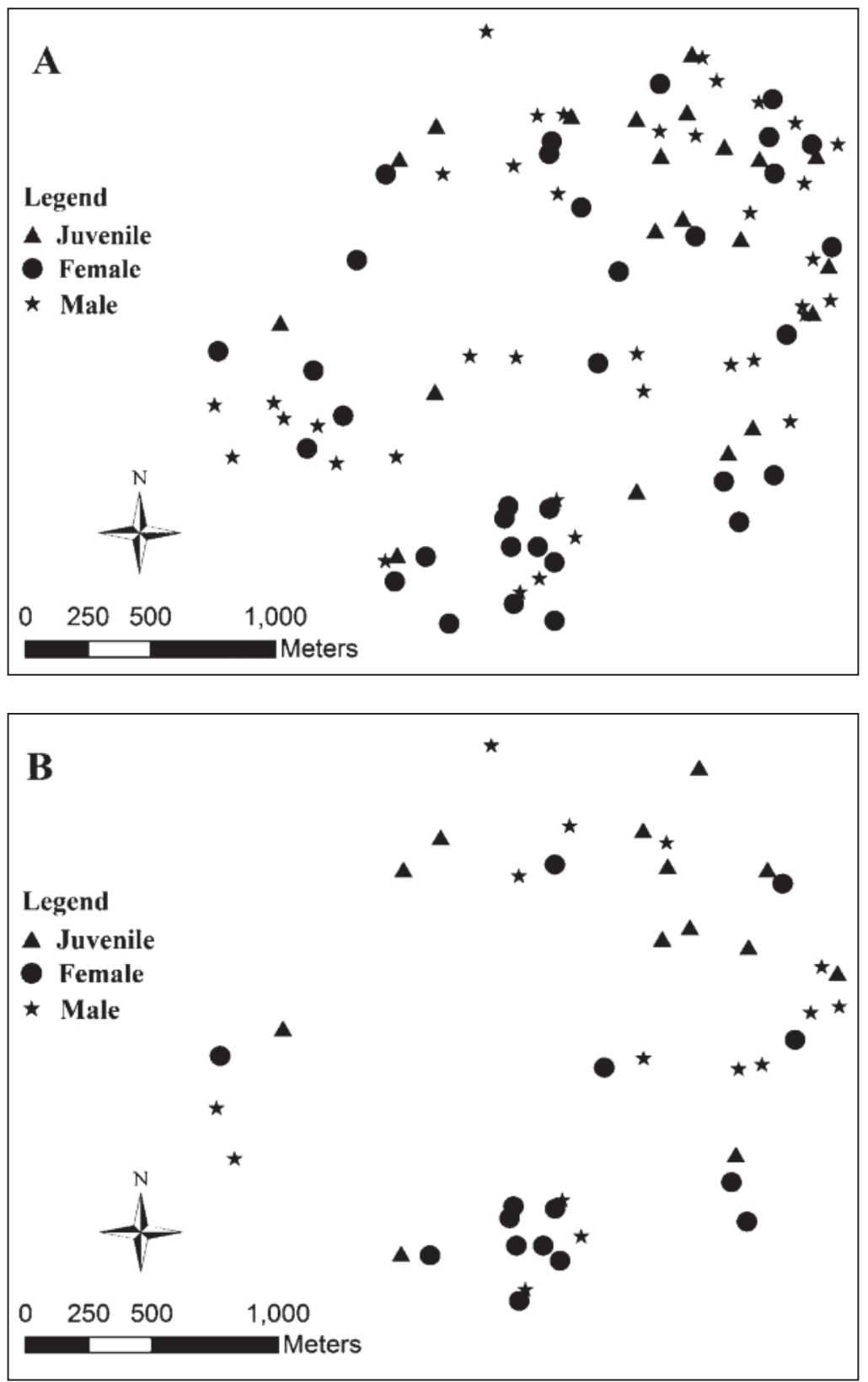

Figure 1. - Distribution of juvenile, male and female Bagassa guianensis trees in the study plot before and (A) after logging (B).

Suriname (VEGA, 1976) and is classified as a pioneer species that is light demanding and presents annual flowering in natural populations. Adult trees can reach 35 to $50 \mathrm{~m}$ in height and more than $190 \mathrm{~cm}$ diameter at breast height (dbh). The population densities are generally very low ( 0.2 trees/ha for $\mathrm{dbh} \geq 45 \mathrm{~cm}$, Silva et al., 2008). Flowering has been observed in trees with a minimum dbh of approximately $40 \mathrm{~cm}$. Pollination is anemophilous with the participation of tiny insects (thrips, order Thysanoptera) moving through the wind (MAUÉS, 2006). Fruits are produced annually in populations, but not all female trees produce annually fruits. Each fruit has many seeds, and seeds can remain viable in the soil for a long time. Seed dispersion occurs by both gravity and animals (VEGA, 1976).

\section{Study site and sampling}

The study was carried out in a 500 ha experimental plot established in a continuous natural forest located alongside highway BR-163, in the Tapajós National Forest $\left(2^{\circ} 51^{\prime} \mathrm{S}, 54^{\circ} 57^{\prime} \mathrm{W}\right.$, and $175 \mathrm{~m}$ above sea level), $83 \mathrm{~km}$ south of San- 
tarém, Pará State, Brazil (Figure 1). The area is located in the Belterra Plateau and has a humid tropical climate, with an annual rainfall ranging from 1900 to $2110 \mathrm{~mm}$, and mean monthly temperatures between 24 to $26^{\circ} \mathrm{C}$, throughout the year. The area is covered by a dense tropical forest classified as terra firme dense ombrophilous forest and was not logged before our study. In the plot, all $B$. guianensis individuals found before logging were mapped, measured dbh and sexed, and collected cambium tissue for DNA extraction. We found 92 B. guianensis trees found before logging (33 females, 38 males and 21 not sexed) and after logging (2003), 43 trees remained (15 females, 15 males and 13 not sexed). Logging intensity within plot was $61 \%$ of trees with dbh $>60 \mathrm{~cm}$, but in the surrounding areas of the plot, the logging intensity was highest $(90 \%$ of tees with $\mathrm{dbh}>45 \mathrm{~cm}$ ). Before logging the dbh ranged from 18 to $197 \mathrm{~cm}$, with a mean of $74.9 \mathrm{~cm}$ and median of $76 \mathrm{~cm}$ and after logging ranged from 18 to $132 \mathrm{~cm}$, with a mean $55 \mathrm{~cm}$ of and median $46 \mathrm{~cm}$. Logging decreased the density of the reproductive population from 0.142 to 0.060 trees/ha (Figure 1). The distance between seed trees where seeds were sampled and male individuals before logging ranged from 57 to 2685 $\mathrm{m}$, with an average of $1143 \pm 689 \mathrm{~m}$ ( \pm standard deviation, SD) and median of $1985 \mathrm{~m}$ and after logging, the distance between the 15 seed trees and 15 males trees ranged from 46 to $2631 \mathrm{~m}$, with an average of $1207 \pm 600 \mathrm{~m}( \pm \mathrm{SD})$, and median of $1272 \mathrm{~m}$. Pollen dispersal was assessed using 488 open-pollinated seeds collected from 18 seed trees in 2003 before the area was logged. As the species present supraannual reproduction and not all female trees produce fruits every year, after logging only ten had their fruits sampled in at least one reproductive event (ARRUDA et al., 2015). After logging, we collected 62 seeds from two seed trees in 2006, 80 seeds from five seed trees in 2007, and 89 seeds from eight seed trees in 2008, totaling 231 seeds post-logging. After logging seeds were collected in general from different seed trees, but were collected from one same seed tree in the three reproductive events and in three same seed tree in the two reproductive events. The collected seeds were planted in nursery at the Embrapa Research Station in Belterra. Cambium samples from adult trees were extracted and stored in microtubes containing buffer solution (CTAB buffer (1/3) and ethanol $(2 / 3))$ and kept on ice until storage at $-20^{\circ} \mathrm{C}$; leaves from seedlings (seeds) were collected and stored in tubes containing silicagel for drying.

\section{DNA extraction and microsatellite analysis}

The genetic analyses were conducted using six SSR loci (Bg14, Bg16, Bg28, Bg32, Bg35, and Bg39) isolated and characterized for B. guianensis (VINSON et al., 2010). Details on DNA extraction, amplification, and genotyping for the six microsatellite loci are described in VINSON et al. (2010).

\section{Paternity analysis}

We estimated the non-exclusion probability of each parent pair before and after logging $\left(P_{p}\right)$ using the CERVUS 3.0 program (MARSHALL et al., 1998). We accepted the paternity when the trio of seed-mother-father presented a maximum mismatch of one. The probability of cryptic pollen flow, or that a foreign pollen donor could have multilocus genotypes that could be generated by a local tree, was estimated following Dow and Ashley (1996). Paternity analysis of each seed before and after logging was carried out on a maximum-likelihood categorical parentage assignment (Meagher, 1986). Paternity was assigned by comparing genotypes of mother trees, seeds, and male candidates, using CERVUS program, based on the $\Delta$ statistic, which is the difference between the LOD (logarithm of the odds) scores of the two most probable pollen parent candidates (MARSHALL et al., 1998). To assess paternity before logging, we used the 38 identified males and eight unsexed individuals with a dbh $\geq 39 \mathrm{~cm}$ as pollen donor candidates, totalling 46 individuals. After logging, we used the 15 remaining males and seven unsexed individuals, with $\mathrm{dbh} \geq 39 \mathrm{~cm}$, totalling 22 individuals. To find the critical value of $\Delta$ for $80 \%$ (relaxed) confidence level in the paternity analyses, simulations were conducted using 50000 repetitions, 0.01 as the proportion of mistyped loci, and $70 \%$ proportion of sampled pollen parents, resulting in 66 [(100\%x46)/70\%] male trees before logging and $32[(100 \% \times 22) / 70 \%]$ male trees after logging as probable pollen parents for each seed. In the analyses, the allele frequencies calculated for adult trees were used as reference allele frequencies. To increase the precision in the paternity analysis, the minimum number of loci required for parentage analysis was set to five. If a candidate male had an $\Delta$ exceeding the crit- 
ical value of $\Delta$, determined from simulations, it was considered a true potential parent. If a seed had no potential pollen donor in the plot, it was considered as having no male parent within plot and we assumed that the mating event involved pollen flow from outside the plot. For each seed tree, and considering all seed trees together, we calculated the proportion of pollen immigration $\left(m_{i}=n_{i} / n\right.$; where $n_{i}$ is the number of immigrants and $n$ is the total number of sampled seeds). To estimate the rate of mating among relatives, we calculated the pairwise coancestry coefficient $(\theta)$ among seed trees and assigned pollen donors by paternity analysis based on the method described in LOISELLE et al. (1995) and using the Spagedi 1.3 program (HARDY and VEKEMANS, 2002). Values of $\theta$ lower than expected between half-sibs (0.125) were assumed as zero (unrelated). The rate of mating among relatives $\left(t_{r}\right)$ was calculated as: $t_{r}=n_{r} / n$, where $n_{r}$ is the number of seeds originated from mating among relatives and $n$ is the total num- ber of seeds sampled in each seed tree. The standard error of average mating among related individuals was estimated assuming binomial distribution, as:

$$
S E\left(t_{r}\right)=\sqrt{\left.t_{r}\left(1-t_{r}\right) / m\right)},
$$

where $m$ is the number of sampled seed trees in the plot. The inbreeding of seeds resulting from mating among relatives $\left(F_{r}\right)$ was estimated using the individual fixation index $(F)$, also calculated using Spagedi 3.1 program (HARDY and VEKEMANS, 2002). Values of $F_{r}$ lower than 0.125 were assumed as zero. Statistical significance of mean $F_{r}$ values was tested by 1,000 permutations of alleles among individuals, associated to a Bonferroni correction for multiple tests $(95 \%$, $\alpha=0.05$ ).

From the paternity analysis, pollen dispersal distance $(D)$ was calculated for seeds based on the Euclidean distance among two points. In order to investigate if male mating success was

Table 1. - Profiles of sample size and mean and variation pollen flow among seed trees determined by paternity analysis before and after logging in one Bagassa guianensis plot.

\begin{tabular}{|c|c|c|c|c|}
\hline Index & Batore & & After & \\
\hline & & ariation among & & Variation among \\
\hline Index & Menti \pm SI & seidid tretes & Henth \pm \$1 & secd triecs \\
\hline Number of assigred seeds & 40.7 & $15-26$ & 191 & $3-27$ \\
\hline Number of not assigned seeds & 8.5 & $1-9$ & 40 & $0-14$ \\
\hline Mean poller dispersal distatece (m) & $1263 \pm 629$ & $975-1505$ & $1176 \pm 691$ & $628-1993$ \\
\hline Median polleu dispersal distance (m) & 1262 & - & 1006 & - \\
\hline Mininimu'maximun distasec (m) & $131: 26.77$ & $1710-2637$ & $131: 2501$ & $1000-2501$ \\
\hline Ettective jollinarion meighbor area: $A_{\text {ir, }}$ f has & 248 & $71-575$ & 300 & $15-529$ \\
\hline \multicolumn{5}{|l|}{ Mating anong relacives } \\
\hline Mean coancestry among seed tree and lather $(9$,$) :$ & $0.206 \pm 0.059$ & $0.130-(1.389$ & $0.207 \pm 0.047$ & $0-0.281$ \\
\hline Number of assigtucd sends amona relatives & 83 & $1-13$ & 33 & $0-8$ \\
\hline Mating amongr relatives rale: $l_{y}$ - mean $\pm \mathrm{SE}$ & $0.17 \pm 0.090$ & $0.0 .3-0.43$ & $0.11 \pm 0.08$ & $0-0.41$ \\
\hline Nent fixntion index from mating nomong telarines: $F_{y}$ & 0.222 & $0-0434$ & 0.126 & $0-0.570$ \\
\hline Pollen dispersal distatloe (m) & $1058 \pm 626$ & $493-2004$ & $727 \pm 670$ & $1,32-2,312$ \\
\hline Maximum distatuce $(m)$ & 1262 & $69 .-3488$ & 2402 & $150-2462$ \\
\hline Elfective number ot pollen donors: $W_{p !}$ & 187 & $5-554$ & 90 & $3.3-193$ \\
\hline Patertity comclatiots: $r_{i}$ & 0.108 & $0.0150-0.233$ & 0.193 & {$[0.09]-0.375$} \\
\hline
\end{tabular}

SD and SE are the standard deviation and standard error, respectively.

Explain the symbol of square from the table. 
a function of distance between males and seed trees, we compared the curve of frequency of effective pollinating male parents with the frequency distribution of the distances among all males and seed trees, using the Kolmogorov-
Smirnov test (SokAL and RoHLF, 1995). As the sample size after logging was small, we grouped all studied post-logging years for this analysis. The effective neighbourhood pollination area $\left(A_{e p}\right)$ was calculated for each seed tree from the


Figure 2. - Frequency distribution of pollen dispersal distance and distance among seed trees where seed were collected to male trees before logging (a) and after logging (b), and the distance before and after logging (c) in one Bagassa guianensis plot. 
Table 2. - Results of pollen flow and dispersal determined by paternity analysis before and after logging in four other tree species studied in the same plot.

\begin{tabular}{|c|c|c|c|c|c|c|c|c|c|}
\hline Spenties & Treatureint & $\begin{array}{l}\text { Areat } \\
\text { ihaj }\end{array}$ & Tyestibat & Pollination & $\begin{array}{l}\text { Pollell } \\
\text { tlow } \\
\text { fij }\end{array}$ & $\begin{array}{l}\text { Wealln } \\
\text { distance } \\
\text { (ni) }\end{array}$ & $\begin{array}{l}\text { Maximitum } \\
\text { int\} }\end{array}$ & $\begin{array}{l}A(w) \\
\text { (ha) }\end{array}$ & Aेturghri \\
\hline Hymenact ouburil & After & 546 & 0.101 & Rits: & 38 & 952 & 2204 & 178 & CARAFIRO Et all . 201 I \\
\hline Jipierpe odora & Refore & 546 & 0.140 & Bets & 77 & 1026 & 1.304 & 111 & VINSCIV a الة 2015 \\
\hline \multirow[t]{2}{*}{ Focaronda dopuid } & Bstor: & 200 & 1.280 & $\mathrm{~B} \mathrm{~L}^{2} \mathrm{CS}$ & 49 & 515 & 10,34 & 2 & VINSON et al .2015 \\
\hline & Afte:T & 2010 & 1.070 & Busia & 4.3 & 4.36 & 1060 & I & 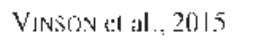 \\
\hline \multirow[t]{2}{*}{ Shmplonite sobulifere } & B.tare 2002 & 300 & 0332 & Flu[3nningtoirds & 35 & 907 & 2832 & 267 & Cantelko et al ., 2069 \\
\hline & Before 2013.4 & 500 & 0.3 .72 & Flumustuingbirds: & 43 & 963 & 26.53 & 185 & 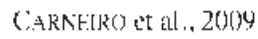 \\
\hline
\end{tabular}

axial pollen-dispersal variance $\left(\sigma^{2}\right)$, assuming a circular area around a central seed tree, $A_{e p}=2 \pi \sigma^{2}$ (Levin, 1988). To investigate the association between male fertility and dbh, or the capacity of large pollen donors to generate more offspring than smaller trees, we used a linear regression analysis, estimated with SAS program (SAS, 1999).

\section{Results}

\section{Paternity assignment before logging}

The overall non-exclusion probability of parent pairs $\left(P_{p}\right)$ across six microsatellite loci was 0.00148 . In the paternity analysis before logging, we considered not sexed trees with $\mathrm{dbh} \geq 39 \mathrm{~cm}$ as putative male candidates, totalling 46 potential male candidates (38 males +8 individuals not sexed). The probability of cryptic pollen flow or the probability of a seed to be erroneously assigned for a male candidate within plot, when the true father was located outside plot was $0.07\left[1-(1-0.00148)^{46}\right.$, where 46 is the number of candidate male parents]. Of the 488 analyzed seeds before logging, we found 403 seeds receiving pollen from donors located within the plot, suggesting that the other 85 unassigned seeds (17\%) were probably fathered by male trees located outside the plot (Table 1). The number of seeds that could be matched to unrelated adults by chance was estimated as 28 ( $403 \times 0.07)$. The estimated pollen gene flow, corrected for cryptic pollen flow, was estimated as $23 \%$ [100\%(85+28)/488]. Pollen migration among seed trees ranged from 4 to $38 \%$ (Table 1). Seeds were fathered by 42 of the 46 putative male candidates within the plot. Seven of the eight unsexed trees with a $d b h \geq 39 \mathrm{~cm}$ were determined as male trees. Thus, the sex ratio is 33 females: 45 males, or 0.73:1. Each male tree fathered from one to 32 seeds, while 10 males fathered $49 \%$ of the assigned seeds. However, there is no significant association between the number of seeds fertilized by pollen donors and the dbh of assigned pollen donors $\left(R^{2}=0.005\right.$, $P>0.05, \mathrm{df}=86$ ).

\section{Paternity assignment after logging}

The overall non-exclusion probability of parent pairs $\left(P_{p}\right)$ across six SSR loci was 0.00517 . In the paternity analysis after logging, we also considered not sexed trees with $d b h \geq 39 \mathrm{~cm}$ as a putative male candidate, totalling 22 potential male candidates ( 15 males +7 individuals not sexed). The probability of cryptic pollen flow was 0.11 [1-(1-0.00517) ${ }^{22}$, where 22 is the number of candidate pollen parents. Of the 231 analysed seeds, pollen donors could be assigned within the plot for $191(83 \%)$ seeds for the total three years sample (Table 1). The other 40 unassigned seeds (17\%) were likely fathered by male trees located outside the plot. The estimated pollen flow, corrected for cryptic gene flow was $26 \%$. Pollen immigration after logging ranged among seed trees from 0 to $47 \%$ (Table 1). Twenty-one putative pollen parents located within the plot fathered at least one seed (maximum of 20 seeds). All seven remaining unsexed individuals with a dbh $\geq 39 \mathrm{~cm}$ were determined as males, resulting in a sex ratio of 15 females: 22 males, or $0.68: 1$. Ten putative pollen donors fathered about $67 \%$ of the total seeds assigned after logging, but no significant association 
between the number of seeds fertilized by pollen donors and the dbh of assigned pollen donors after logging was detected $\left(R^{2}=0.048, P>0.05\right.$, $\mathrm{df}=44$ ).

\section{Distance of pollen movement}

Although before and after logging pollen was dispersed within the plot over long distances (maximum before $=2637 \mathrm{~m}$; after $=2501 \mathrm{~m}$ ), mean pollen dispersal distance decreased after logging (Table 1, Figure 2). The mean pollen dispersal distance among seed trees before logging ranged from 975 to $1505 \mathrm{~m}$ and after logging from 628 to $1993 \mathrm{~m}$ (Table 1). We tested if the distance among seed trees and assigned pollen determined the number of seeds fertilized by pollen donors. There was no significant association between the number of seeds fertilized by pollen donors and the distance between the paternal and maternal trees before logging $\left(R^{2}=0.135, P>0.05, \mathrm{df}=16\right)$, but we found a significant association after logging $\left(R^{2}=0.475\right.$, $P>0.05, \mathrm{df}=16$ ), indicating that after logging mating occurs in high frequency between close near neighbor's females and males trees. We also compared the frequency distribution of pollen dispersal distance a the distance among males and females trees, to investigate if the distance of male and female trees can explain the patterns of pollen dispersal, using the Kolmogorov-Smirnov test. In agreement whit the previous test based in the correlation, the Kolmogorov-Smirnov test between the frequency of estimated pollen dispersal distance and the distance among putative pollen donors and the seed trees was significant before logging $(D=0.125, P=0.001)$, indicating that the distance among potential male parents and seed trees cannot explain the observed mating patterns. After logging, we found no significant difference $(D=0.113, P=0.130)$, indicating that distance among potential male parents and females can explain the observed mating patterns. We also compared the frequency distribution of pollen dispersal distance before and after logging and found significant difference between the frequency distribution of pollen dispersal before and after logging $(D=0.127$, $P=0.030)$. The effective neighborhood pollination area $\left(A_{e p}\right)$ or, the circular area around a seed tree in which $63 \%$ of pollen donors that mated with the seed tree are located was lower before logging (248 ha) than the after logging (300 ha).

\section{Mating among relatives}

We estimated the coancestry coefficient between seed trees and assigned pollen donor $\left(\theta_{r}\right)$ to detect the rate of mating among relatives. The pairwise coancestry coefficient between seed trees and assigned pollen donors $\left(\theta_{r}\right)$ before logging ranged from -0.292 to 0.389 and after logging ranged from -0.313 to 0.342 . Assuming $\vartheta_{r}$ values $\geq 0.125$ as related individuals, the mean pairwise $\theta_{r}$ was similar before and after logging (0.206 and 0.207 , respectively, Table 1) and the mean among seed trees ranged before logging from 0.130 to 0.389 and after logging from 0.131 to 0.281 (Table 1). The rate of mating among relatives before logging ranged among seed tree from 0.03 to 0.43 (mean of 0.17 ) and after logging from 0 to 0.41 (mean of 0.11). As mating among relatives produce inbreeding we estimated also the fixation index for assigned seed from related seed trees and assigned pollen donors. The mean fixation index for inbred seeds $\left(F_{r}\right)$ was significant $(P<0.05)$ higher than zero before logging (mean of 0.222 ) and after logging (mean of 0.126). The mean pollen dispersal distance among related seed trees and assigned pollen donors decreased after logging, with a mean of $1058 \mathrm{~m}$ before to $727 \mathrm{~m}$ after logging.

\section{Discussion}

\section{Pollen flow}

Our results show similar pollen flow for B. guianensis both before (23\%) and after logging (26\%), indicating extensive pollen movement in the area and that logging did not affect pollen migration. However, pollen flow was lower than observed for four other tree species studied in the same plot (Table 2) before logging (ranging from 35 to $77 \%$ ) and three species investigated after logging (ranging from 38 to 89\%) (LACERDA et al., 2008; CARNEIRO et al.; 2011; VInson et al., 2015). The low density of $B$. guianensis trees, associated to the fact species is dioecious and mating occurs only between female and male trees and, that not all trees flowering all years are the probably the cause of lower pollen immigration for B. guianensis than for the other studied species; Dipteryx odorata, Jacaranda copaia, Hymenaea courbaril and Symphonia globulifera all have higher population densities before and after logging than B. guianensis. 


\section{Pollen dispersal distance and patterns}

Pollen was dispersed over long distances before and after logging, reaching a maximum of $2637 \mathrm{~m}$ within plot. The pollen dispersal distance depends on distance among reproductive conspecifics, the level of synchronicity in the flowering phenology, male fertility, pollination vector and pollinator behaviour (DUNPHY et al., 2004; Dick et al., 2008; KLEIN et al., 2008; Degen and Sebbenn, 2014). For B. guianensis, male flowering phenology is perfectly synchronous with female flowering (SILva et al., 2008), but not all male and female trees produced flowers in each of the studied years, which can change the actual distance among coespecific reproductive male and female trees each year, thus changing the pollen dispersal distance. Thus, as our estimates of pollen dispersal distance before logging is based on only one reproductive event and after logging on three reproductive events, our results comparing before and after logging must be interpreted with caution. Long distance pollen dispersal in B. guianensis is somewhat unexpected since the species is pollinated by very tiny insects (thrips). However, thrips are able to remain airborne for long periods of time and they can be carried over long distances, up to $30 \mathrm{~km}$, by air currents and wind (LEWIS, 1973). Another explanation for the long distance pollen dispersal detected in our study could be "carryover", when pollen is deposited in the floral structures of different "intermediary" trees before reaching the stigma of a $B$. guianensis female flower.

The pattern of pollen dispersal distance before and after logging was similar, the isolation by distance. However, our results show that the median pollen dispersal distance decreased from before $(1269 \mathrm{~m})$ to after logging $(1006 \mathrm{~m})$, suggesting that logging increased the intensity of this pattern. Although, the observed mating pattern before logging is not determinate by distance between female and male trees, after logging this distance explain the mating patterns. As logging reduced the population density of reproductive trees, it probably affected the pollinators' foraging behaviour, altering pollen dispersal patterns. Decreases in pollen dispersal distance after logging were also detected for D. odorata and J. copaia (Table 2) and Entandrophragma cylindricum (LOURMAS et al., 2007).
The mean pollen dispersal distance before and after logging in B. guianensis was also higher than that of three other species studied in the same plot: before logging ranging from 515 to $1026 \mathrm{~m}$; after logging ranging from 456 to 952 m (Table 2) (LACERDA et al., 2008; CARNEIRO et al.; 2011; VINSON et al., 2015). In the present case, these differences occurred because $B$. guianensis is dioecious, with a sex ratio before of 0.73:1 (33 females: 46 males) and after logging of 0.68:1 (15 females: 22 males) and mean distance among female and males before logging $(1262 \mathrm{~m})$ and after logging $(1207 \mathrm{~m})$ is higher than trees of the other species. Furthermore, the population density of putative pollen donors in $B$. guianensis was lower before and after logging than $D$. odorata, $H$. courbaril, and $J$. copaia, as already discussed. Thus, B. guianensis pollinators must fly longer distances between male and female trees in comparison with the other species. Thrips can carried over long distances (up to $30 \mathrm{~km}$ ) by air currents and wind (LEWIS, 1973) and the pollen is probably deposited in the floral structures of intermediary trees before reaching the stigma of a $B$. guianensis female flower. Thus, the behaviour of the pollinator of $B$. guianensis is probably the cause of the great mean pollen dispersal distance before and after logging than observed in the other mentioned species.

However, it is important to note that all estimates of pollen flow for $B$. guianensis, as well as the other cited species, are likely underestimates due to the substantial amount of pollen immigration found for all studied species.

The difference between the frequency distribution of pollen dispersal and the distance of all males in relation to females after logging, as well as the rate of mating among relatives and correlated mating detected before and after logging, suggest restrict mating potential during reproductive events (Figure 2b, Table 1). Although practically all males fertilized at least one of the assigned seeds, a small number (10) fathered a large majority of the seeds before $(49 \%)$ and after logging (67\%). This result clearly indicates restrict mating potential in the evaluated mating events, especially after logging.

\section{Effective pollination neighbour area}

The effective neighbourhood pollination area $\left(A_{e p}\right)$ is defined as a circular area in which $63 \%$ 
of pollen donors that mated with a seed tree are expected to be located (LEVIN, 1988). Although variable over the studied years and seed trees before and after logging, seed trees exhibited a large $A_{e p}$ before (248 ha) and after logging (300 ha). As noted above, these results may underestimate the true $A_{e p}$ due to pollen gene flow. The $A_{e p}$ after logging for $B$. guianensis is larger than estimated for the other tree species studied in the same plot (Table 2); this is related to the lower population density of putative pollen donors before and after logging than found for $D$. odorata, $H$. courbaril, and $J$. copaia. The large $A_{e p}$ observed for $B$. guianensis likely makes this species resilient to reductions in population density caused by fragmentation or selective logging (SILVA et al., 2008). After logging, reproductive trees would not be isolated if trees of different sexes are maintained within the pollination neighbourhood area.

\section{Mating among relatives}

The estimated rate of mating among relatives $\left(t_{r}\right)$ was variable among years and seed trees before and after logging. All seed trees before logging mated with related individuals (mean $t_{r}=0.17$ ), but after logging not all seed trees mated with relatives (mean $t_{r}=0.11$ ). Similar values and patterns (before $=0.171$; after logging $=0.135$ ) were detected by ARRUDA et al. (2015) using the same data set and mixed mating model implemented in MLTR (RITLAND, 2002). Mating among relatives in dioecious species can occur if species are self-compatible and populations have spatial genetic structure (SGS) or if there are some related individuals within the population. SiLva et al. (2008) showed that before logging this population presented SGS up to $300 \mathrm{~m}$, but noted an absence of SGS after logging. The absence of significant SGS does not indicate a lack of related individuals in the population, but rather an absence of association between mean pairwise relatedness and mean spatial distance among individuals. Thus, after logging, some related individuals of different sexes remained in the population and mating occurred between them. Based on pollen dispersal results, the distance between these related male and female trees ranged before logging from 493 to $2004 \mathrm{~m}$ and after logging from 132 to $2312 \mathrm{~m}$. Mating among related individuals produces inbreeding at the same level as the coancestry among the parents. Our esti- mate of mating among relatives $\left(t_{r}\right)$ is based on the assumption that related parents are at least half-sibs $\left(\theta_{r}=0.125\right)$ and only pairwise coancestry coefficient $\left(\theta_{r}\right)$ between seed trees and assigned pollen donor $\geq 0.125$ were assumed as result in mating among relatives. Thus, our estimated maybe is underestimated, because cousins $\left(\theta_{r}=0.0625\right)$ can also be present in the population. The mean $\theta_{r}$ was similar before (0.208) and after logging (0.212). The mean inbreeding for seeds identified as originating from mating among relatives $\left(F_{r}\right)$ before logging (0.222) was similar to $\theta_{r}$, but after logging (0.126) the $F_{r}$ was lower than $\theta_{r}$.

\section{Final considerations}

Our results reveal a complex web of mating among $B$. guianensis trees within the plot and pollen immigration from outside plot, both before and after logging. Logging did not affect pollen immigration into the study area and pollen was dispersed over long distances within the plot, both before and after logging. However, logging decreased the mean pollen dispersal distance, the pattern of mating was the isolation by distance and mating among trees depends on the spatial distance among male and female reproductive individuals. In contrast, logging increased the mean effective neighbourhood pollination area due increased in the variance in the distance between the sampled seed trees and assigned pollen donors. These results indicates that after logging the mating occurred in higher frequency between close near neighbour individuals and the decrease in the population density increased correlated mating. As the logging decreased the SGS in adults by removing some near neighbour related trees (SILVA et al., 2008), the mating among relatives rate was also decreased, resulting in open pollinated seeds with lower levels of inbreeding than before logging. The logging caused a genetic bottleneck, resulting in a remaining reproductive population with low genetic diversity (SILva et al., 2008). As pollen flow was similar before and after logging and in the surrounding population the logging intensity was higher $(90 \%$ of trees with $\mathrm{dbh}>50 \mathrm{~cm}$ ) than in the plot $(62 \%$ of trees with $\mathrm{dbh}>62 \mathrm{~cm}$, Silva et al., 2008), we can expect the immigration of some new alleles from outside plot, but lower than occurred before logging. The overall results suggest that reproductive trees must be maintained in the plot and around logged popu- 
lation, using lower logging intensities (LI) above the minimum cutting diameter in order to decrease the relatedness and not strongly decrease the genetic diversity of subsequent generations. Furthermore, simulation studies of the effects of logging intensity above minimum cutting dbh and cutting cycles with $B$. guianensis, D. odorata, H. courbaril, J. copaia, Manilkara huberi and S. globulifera showed that the logging rule used in Brazil are not sustainable and must be specie-specific due difference in ecology, genetic and reproductive characteristics between the species and based on lower intensity logging above the a highest minimum cutting dbh and in longer cutting cycles than actually used (SEBBENN et al., 2008; Silva et al., 2008; LACERDA et al., 2013; VINSON et al., 2015).

\section{Acknowledgements}

This study was funded by the Brazilian Ministry of Science and Technology. CYNTHIA C.B. ARRUDA was supported by a Conselho Nacional de Ciência e Tecnologia (CNPq/Brazil) scholarship. Alexandre M. Sebbenn, Maristerra R. LEMES, and ROGÊRIO GRIBEL are supported by $\mathrm{CNPq} /$ Brazil research fellowships. The authors also acknowledge the Instituto Chico Mendes de Biodiversidade - ICMBio (MMA/Brazil) for permits to work at the Tapajós National Forest, Santarém-PA and the Laboratório de Genética e de Biotecnologia da Embrapa Amazônia Oriental for logistical support for part of the genetic analyses. The authors would like to thank all the people who contributed to this work, especially Dr. IRACILDA SAMPAIO and ADRIANO Martins. We also tank to Dr. Andre E.B. DE LACERDA by help us with the Figure 1.

\section{References}

Arruda, C. C. B., M. B. Sikva, A. M. Sebbenn, M. Kanashiro, M. R. Lemes and R. Gribel (2015): Mating system and genetic diversity of progenies before and after logging: a case study of Bagassa guianensis (Moraceae), a low-density dioecious tree of the Amazonian forest. Tree Genetics \& Genomes 11: $1-9$.

Ashley, M. V. (2010): Plant parentage, pollination, and dispersal: How DNA microsatellites have altered the landscape. Critical Review in Plant Science 29: 148-161.
Azevedo, V. C. R., K. Kanashiro, A. Y. and D. GratTAPAGLIA (2007): Genetic structure and mating system of Manilkara huberi (Ducke) A. Chev., a heavily logged Amazonian timber species. Journal of Heredity 98: 646-654.

BurczyK, J., S. P. DiFAzio and W. T. AdAms (2004): Gene flow in forest trees: how far do genes really travel. Forest Genetics 11: 1-14.

Carneiro, F., B. Degen, M. Kanashiro, A. E. B. LaCERDA and A. S. SEBBENN (2009): High levels of pollen dispersal in Symphonia globulifera in a dense Brazilian Amazon forest revealed by paternity analysis. Forest Ecology Management 258: 1260-1266.

Carneiro, F. S., A. E. B. Lacerda, M. L. Lemes, R. GRibel, M. Kanashiro, L. H. O. WADT and A. M. SEBBENN (2011): Effects of selective logging on the mating system and pollen dispersal of Hymenaea courbaril L. (Leguminosae) in the Eastern Brazilian Amazon as revealed by microsatellite analysis. Forest Ecology Management 262: 17581765.

Degen, B. and A. M. Sebbenn (2014): Genetics and tropical forests. In: PANCEL, L. and M. KÖLH, editors. Tropical Forestry Handbook, $2^{\text {nd }}$ ed. Berlin Heidelberg: Springer Verlag; p. 1-30.

Dick, C. W., F. A. Jones, O. J. HARdy and R. Petit (2008): Spatial scales of pollen and seed-mediated gene flow in tropical rain forest trees. Tropical Plant Biology 1: 20-33.

Dow, B. D. and M. V. Ashley (1996): Microsatellite analysis of seed dispersal and parentage of sampling in bur oak, Quercus macrocarpa. Molecular Ecology 5: 615-627.

DunPhy, B. K., J. L. HAMrick and J. SchwAGERL (2004): A comparison of direct and indirect measures of gene flow in the bat-pollinated tree Hymenaea courbaril in the dry forest life zone of south-western Puerto Rico. International Journal Plant Science 165: 427-436.

Ellestrand, N. C. (2014): Is gene flow the most important evolutionary force in plants? American Journal of Botany 21: 737-753.

HARDY, O. and X. VEKEMANS (2002): SPAGeDI: a versatile computer program to analyze spatial genetic structure at the individual or population levels. Molecular Ecology Notes 2: 618-620.

Hawley, G. J., P. G. SchaberG, D. H. DeHayes and J. C. BRIssette (2005): Silviculture alters the genetic structure of an eastern hemlock forest in Maine, USA. Canadian. Journal of Forest Resources 35: 143-150.

Klein, E. K., N. Desassis and S. Oddou-Muratorio (2008): Pollen flow in the wild service tree, Sorbus torminalis (L.) Crantz. IV. Whole interindividual variance of male fecundity estimated jointly with the dispersal kernel. Molecular Ecology 17: 33233336.

Lacerda, A. E. B., E. R. Nimmo and A. M. Sebbenn (2013): Modelling the long-term impacts of logging 
on genetic diversity and demography of Hymenaea courbaril. Forest Science 59: 15-26.

LACERDA, E. B. L., A. M. SEBbenn and M. KanAshiro (2008): Long-pollen movement and deviation of random mating in a low-density continuous population of Hymenaea courbaril in the Brazilian Amazon. Biotropica 40: 462-470.

LEvin, D. A. (1988): The paternity pool plants. American Naturalist 132: 309-317.

LEwIS, T. (1973): Thrips: their biology, ecology and economic importance. Academic Press, New York, New York, USA.

Loiselle, B. A., V. L. Sork, J. NAson and C. Graham (1995): Spatial genetic structure of a tropical understory shrub, Psychotria officinalis (Rubiaceae). American Journal of Botany 82: 1420-1425.

Lourmas, M., F. KJellberg, H. Dessard, H. I. Joly and M-H. Chevallier (2007): Reduced density due to logging and its consequences on mating system and pollen flow in the African mahogany Entandrophragma cylindricum. Heredity 99: 151-160.

Lowe, A. J., D. Boshier, M. WArd, C. F. E. Bacles and C. NAVARRO (2005): Genetic resource impacts of habitat loss and degradation; reconciling empirical evidence and predicted theory for Neotropical trees. Heredity 95: 255-273.

Marshall, T. C., J. Slate, L. E. B. KruUK and J. M. PEMBERTON (1998): Statistical confidence for likelihood-based paternity inference in natural populations. Molecular Ecology 7: 639-655.

MAUÉs, M. M. (2006): Estratégias reprodutivas de espécies arbóreas e a sua importância para o manejo e conservação florestal: Floresta Nacional do Tapajós (Belterra-PA). PhD. Thesis, University of Brasília, 218 pp.

MEAGHeR, T. R. (1986): Analysis of paternity within a natural population of Chamaelirium luteum. 1. Identification of most-likely male parents. American Naturalist 128: 199-215.

RAJora, O. P., M. H. Rahman, G. P. Buchert and B. P. DANCIK (2000): Microsatellite DNA analysis of genetic effects of harvesting in old-growth eastern white pine (Pinus strobus) in Ontario, Canada. Molecular Ecology 9: 339-348.
RITLAND, K. (2002): Extensions of models for the estimation of mating systems using $\mathrm{n}$ independent loci. Heredity 88: 221-228.

SAS Institute Inc. (1999): SAS Procedures Guide. Version 8 (TSMO) SAS Institute Inc., Cary, NC.

Sebbenn, A. M., J. C. Licona, B. Mostacedo and B. DEGEN (2012): Gene flow in an overexploited population of Swietenia macrophylla King (Meliaceae) in the Bolivian Amazon. Silvae Genetica 61: 212-220.

Sebbenn, A. M., B. Degen, V. C. R. Azevedo, M. B. Silva, A. E. B. Lacerda, A. Y. Ciampi, M. Kanashiro, F. S. Carneiro, I. Tompson and M. D. LOVELESS (2008): Modelling the long term impact of selective logging on genetic diversity and demographic structure of four tropical tree species in the Amazon forest. Forest Ecology and Management 254: 335-349.

Silva, M. B., M. Kanashiro, A. Y. Ciampi, I. Tompson and A. M. SEBBENN (2008): Genetic effects of selective logging and pollen gene flow in a low-density population of the dioecious tropical tree Bagassa guianensis in the Brazilian Amazon. Forest Ecology and Management 255: 1548-1558.

SoKAL, R. R. and F. J. RoHLF (1995): Biometry: principles and practices of statistics in biological research. Third Edition. W. H. Freeman and Company, New York.

VEGA, L. (1976): Bagassa guianensis Aubl. Una especie forestal de rapido crecimiento del tropico americano. Boletim do Instituto Florestal. LatAmerica Investigation 50: 3-28.

Vinson, C. C., M. B. Silva, M. I. Sampaio and A. Y. CiAmpi (2010): Microsatellite markers for a dioecious Amazon tree, Bagassa guianensis Aubl. (Moraceae). Molecular Ecology Resources 10: 1106-1108.

Vinson, C. C., M. Kanashiro, S. A. Harris and D. H. BoshiER (2015): Impacts of selective logging on inbreeding and gene flow in two Amazonian timber species with contrasting ecological and reproductive characteristics. Molecular Ecology 24: 38-53. 